\title{
Adorea, Filosofiatik Psikologiara
}

\author{
Mikel Haranburu, Nekane Balluerka eta Arantxa Gorostiaga \\ Psikologia Fakultatea (UPV/EHU)
}

\section{(Courage: from Philosophy to Psychology)}

DOI: $10.1387 /$ gogoa.20361

\begin{abstract}
The philosophical representations of courage and its components have varied throughout history, depending on the authors, the historical epoch and the cultural context. In this article, we will first make a historical tour through different representations of courage from Greek Antiquity to the Contemporary Age. We will point out the features of courage according to representative authors of the different periods: the exposure to the public of the Homeric hero; the intellectualization of the Socratic and Platonic courage; the return to the military vision of courage by Aristotle; the work and humility ethics of the first Christians; the courage in the solitary confrontation to death in the Middle Ages; the disappearance of the construct of courage and the predominance of the combination of mercantile interests in the Modern Age; the rejection of the theory of the middle term by Machiavelli; the vitalist conception of the courage in Spinoza; the courage for the free use of intelligence in Kant; the courage to overcome mediocrity in Nietzsche; the courage to overcome anxiety in the face of non-being and change in Tillich; the courage to act freely and overcome the excessive attachment to life in Arendt; and the courage to speak the truth despite the opposition of influential people in Foucault. Next, we will carry out a brief review of some psychological definitions of courage and establish its fundamental components. Finally, based on the revision of the philosophical theories, we will suggest the incorporation of new components to the psychological definition of courage.
\end{abstract}

Keywords: courage, risk, freedom, anxiety.

\section{Laburpena}

Adorearen eta haren osagaien errepresentazioek aldaketak izan dituzte historian zehar, egileen, aro historikoaren eta kultur testuinguruaren arabera. Arti- 
kulu honetan, lehenik, adorearen errepresentazioen ibilbide historikoa egingo dugu, Greziako Antzinatetik hasi eta Aro Garaikidera arte. Garai ezberdinetako pentsalariek adoreaz emandako deskribapenak agertuko ditugu: heroia jendaurrean bere adorea erakusten, Homeroren arabera; adorearen intelektualizazioa, Sokrates eta Platonen arabera; eremu militarrerako itzulera, Aristotelesen arabera; lanaren eta apaltasunaren etika lehenengo kristauengan; heriotzari bakardadean aurre egiten dion Erdi Aroko adorea; adorearen konstruktuaren desagerpena eta merkataritza-interesen konbinazioaren nagusitasuna, Aro Modernoan; Aristotelesen erdibidearen teoriaren baztertzea, Makiavelorengan; adorearen ikuspegi bitalista, Spinozarengan; adimena askeki erabiltzeko adorea, Kantengan; kaskarkeria gainditzeko adorea, Nietzscherengan; ez-izatearen eta aldaketaren aurrean sortzen den barne-herstura gainditzeko adorea, Tillichengan; modu askean jokatzeko eta bizitzarekiko atxikimendu handiegia gainditzeko adorea, Arendtengan; eta ezberdin pentsatzen duten pertsona boteretsuen aurrean egia esateko adorea, Foucaultengan. Ondoren, adorearen definizio psikologiko batzuk berrikusiko ditugu eta haien osagai nagusiak zein diren ikusiko dugu. Azkenik, teoria filosofikoetan oinarrituta, adorearen definizio psikologikoan beste osagai batzuk sartzea iradokiko dugu.

Gako-hitzak: adorea, arriskua, askatasuna, barne-herstura.

\section{Sarrera}

Antzinatetik aztertu izan dituzte filosofoek adorearen gaia eta pertsona adoretsuen bereizgarriak. Izan ere, adorea nazioen eta herrien ongizaterako eta biziraupenerako bertute garrantzitsutzat hartu izan da. Pertsona adoretsuengatik izan ez balitz, nazio asko beste nazioen mendean egongo ziratekeen eta nazio askotako kideak beste kideen mendean egongo ziratekeen. Pertsona adoretsuei esker, hainbat herri eta nazio era guztietako arrisku eta mehatxuetatik babestu izan dira eta askatasunean bizi dira.

Mendebaldeko filosofiaren historian hasieratik saiatu izan dira idazleak eta filosofoak adorea aztertzen eta definitzen. Garai bakoitzak izan ditu bere adore eta beldur motak, eta garai bakoitzeko pentsalariek aztertu izan dute adorearen gaia. Lan honetan, lehenik, Filosofiaren historian izan diren adorearen errepresentazioak eta errepresentazio horien arteko tirabirak aztertuko ditugu. Bigarrenik, psikologiak bereizi izan dituen adorearen osagaiak deskribatuko ditugu. Azkenik, adorearen azterketa filosofikoak haren azterketa psikologikoari egin diezaiokeen ekarpena ikertuko dugu.

\section{Antzinatekoen adorea}

Antzinateko Grezian adorea, gizontasuna eta gerra elkarri estuki loturik zeuden; gerra gizonezkoek egiten zuten eta adorea gizonezkoekin lotua ageri 
zen (Bassi 2003). Gerlari adoretsuak herria defendatu behar izaten zuen eta adore militarra gizonezkoen adorea zen.

\subsection{Homeroren heroien adorea}

Homeroren heroiak areteari edo bikaintasunari esker bereizten ziren beste gizakiengandik. Bikaintasuna erakusteko aukera heriotzak ematen zion heroiari, eta gerrak heriotzaren aurrean adorea erakusteko aukera ematen zion. Adorea, beraz, energia fisikoarekin lotua zegoen eta jendaurrean erakusten zen. Ekintza heroikoak egiten zituztenek ez zuten barne-motibazioz edo motibazio psikologikoz jokatzen; heroiaren adorea ez zegoen intentzio bati edo erantzukizun bati lotua, eta ez zuen heroiak berak erabakitzen zer egin behar zuen. Homeroren heroien adorea naturaz gaindiko indarren eskuetan zegoen: patuan jartzen zuten konfiantza eta, beraz, beraiek ez zuten ardurarik (Berns et al. 2010).

Homerok dilema bat planteatu zuen Iliadan: Akilesen bizitza laburra eta heriotza heroikoa kontrajarri zizkion Ulisesen maltzurkeriari eta bizitza luzeari. Arriskuari aurre egin eta bizitza laburra izatea erabaki zuen Akilesek; ez zuen zahartzaroan eta ahanzturan galdu nahi izan. Akilesek aintza edo loria hilezkorra nahi zuen; horretarako bizitza arriskatu behar zuen eta, bizitza labur baten ondoren, heriotza goiztiar bat espero behar izan zuen.

Homeroren heroiaren adorea heriotza-arriskuari lotua zegoen: bizitzak baino gehiago balio zuen zerbait bazegoela adierazten zuen adoreak. Jainko hilezkorrek ez zuten adorerik, bizitza galtzeko arriskurik ez zutelako; izaki hilkorrek bakarrik jar zezaketen bizitza jokoan. Gizon adoretsuaren eredua zen Akiles, bere ekintzen bidez publikoki erakutsi baitzuen adorea. Adorea ez zen ezkutuan gertatzen zen zerbait, ikusgarria zen zerbait baizik. Heroiaren berezitasuna eta singulartasuna haren ekintzetan hezurmamitzen zen. Adorea ekintzan agertzen zen kualitatea zen, eta ez izaerari zegokiona; ez zegoen gizon adoretsurik, ekintzak bakarrik ziren adoretsuak (Arendt 1983).

\subsection{Adorea Sokrates eta Platonen arabera}

Homeroren garaian imitaziotzat hartzen zen heziketa: heroia imitatzen ikasi behar zen. Sokratesek eta Platonek kritikatu egin zuten heziketa imitatzailea; haientzat, norberaren erabakietan, arrazoiz hartutako erabakietan, oinarritzen zen heziketa. Sokratesek eta Platonek gerraren eremutik moralaren eremura eraman zuten adorea; barnekotasun-maila bat eman zioten gizakiaren portaera adoretsuari eta beste arrisku mota batzuekin erlazionatu zuten: gaixotasunekin, txirotasunarekin eta abarrekin. Platonek ekintza adoretsuen motibazioa eta ekintzailearen erantzukizuna aztertu zituen; ordura arte ar- 
duragabea zen heroi homerikoa, arduratsu, autonomo eta borondate askearen jabe bihurtzen hasi zen. Adorearen nozioa moralizatu, intelektualizatu eta pertsonaren barne-motibazioekin erlazionatu zen. Adorea ez zen, beraz, jainkoek bultzatuta heroiek egiten zuten balentria bat. Adorea ez zetzan kanpoko arriskuak gainditzean, baizik eta barneko beldurrak, desirak eta etsaiak garaitzean (Jeanmart eta Blésin 2009).

Adorea eta jakinduria, ekintza eta diskurtsoa, elkarrekin josi zituzten Sokratesek eta Platonek. Pentsamenduaren eta ekintzaren arteko harremana oinarritzat hartuta, adorea eta jakinduria tirabiran eta elkartuta ikusten zituzten; esaten zuten ez zegoela jakinduriarik gabeko adorerik. Pertsona adoretsuak balio bat begitantzen zuenean, hura lortzeko borroka egiten zuen. Adorea zera zen: ideia on bat gauzatzeko eta intentziotik ekintzara eta errealitate efektibora pasatzeko beharrezkoa zen arimako indarra.

Adorea ezinbestekoa zen filosofiaren baitan, hark lotzen baitzituen filosofoa eta egia esateko beharra. Filosofoak adorea behar zuen egia esateko, esan behar zuen egia ez baitzen egia neutroa, arrisku bat ekar zezakeen egia baizik. Lausenguari aurre egin eta adorez esan behar zuen egia. Arriskua zekarten egiak esateko adorea edo zintzotasuna zen parresia. Parresia lausenguaren aurkakoa zen: parresia praktikatzen zuenak egia esaten zuen solaskidearen portaeraz eta haren autonomia sendotzen zuen; aldiz, lausenguak solaskidearen mendekotasuna sortzen zuen eta, horrela, lausengatua lausengatzailearen mende gelditzen zen. Horregatik, benetako demokraziak egia esateko adorea edo parresia sustatu eta lausengurako joera kontrolatu behar zuen. Lausengua eta demokrazia elkarren etsaiak ziren (Foucault 2009).

Protagorasen iritziz, bertute guztiak bertuteak ziren, baina bertute bakoitzak eboluzio independentea zuen: bertute batean aurrera egiteko ez zen beharrezkoa bertute guztietan aurrera egitea; bertute bat eduki zitekeen, besteak eduki gabe; gerta zitekeen pertsona batzuk zuzengabeak, ezjakinak eta desorekatuak izatea, eta aldi berean oso adoretsuak izatea; era berean, gerta zitekeen nola jokatu jakin arren, horrela ez jokatzea, emozio batzuen (atseginaren, beldurraren edo beste bulkadaren baten) eraginez.

Sokrates ez zegoen ados Protagorasekin; harentzat, adorea ez zen jakinduriatik eta beste bertuteetatik independentea. Sokratesek pentsatzen zuen pertsona adoretsuak ezagutza zuzenaren arabera jokatzen zuela. Haren iritziz, inork ez zuen aukeratzen, jakinaren gainean, bere ustez beste portaera bat baino okerragoa zen portaerarik; ez pertsona koldarrek, ez pertsona adoretsuek, aukeratzen zuten beldur handiena ematen zien hautabidea. Sokratesen arabera, pertsona adoretsuaren eta koldarraren arteko aldea ez zetzan objektu beldurgarriaren aurka egitean ala ez egitean, baizik eta beldur izatea zerk merezi zuen eta zerk ez zuen merezi jakitean. Sokratesentzat, adoretsuak beti zekien zeri izan behar zion beldurra eta zeri ez (Gavray 2009). 
Platonek Laches elkarrizketan adorearen gaia landu zuen. Platonek gerra asko (Espartaren kontrakoa, Persiako gerra...) ezagutu zituen bere bizialdian. Laches Platonen lan goiztiarretako bat da. Sokratesek eta Atenasko jeneralek (Laches eta Nizias) entrenamendu militarraz eta adoreaz dihardute nagusiki Lachesen, baina beste adore mota batzuez ere badihardute: gaixotasunaren aurrean, txirotasunaren aurrean edo estatuko auzien aurrean behar den adoreaz. Sokrates bera adore filosofikoaren eredutzat hartu zuten, heriotzaren aurrean agertu zuen biziera adoretsuagatik (Platon K.a. 399-385; Kraut 2004).

Lachesi Sokratesek galdetzen dio zer den adorea. Lachesek erantzuten dio etsaiaren aurrean aurkitzen denean ihes egiten ez duena dela gizaki adoretsua, gudarostearen lerroetan jarraitzea eta etsaia egoztea erabakitzen duena. Sokratesek galdetzen dio ea, eszitek egiten zuten moduan, lerroak utzi eta ihes eginez etsaia erasotzen duena ez al den ausarta; Lachesek onartzen du halako soldaduak ere adoretsuak direla. Sokratesek adoreaz egindako galderari Laches jeneralak honela erantzuten dio: etsai bat ikusten duenean, harenganantz joaten dela pertsona adoretsua, harekin borroka egitera. Sokratesek esaten dio hori adorearen adibide ona dela, baina ez duela adore mota guztientzat balio, ekintza adoretsu guztietan ez delako kanpoko etsai bat erasotzen. Sokratesek adore mota guztiei buruzko galdera egiten dio: gerrarako adorea, itsasoan nabigatzeko adorea, gaixotasunari aurre egiteko adorea, norberaren gutiziei aurre egiteko adorea. Galdetzen dio adore mota horiek guztiek zer zuten berdinetik. Lachesek erantzuten dio arimaren tinkotasun moduko bat dela. Sokratesek Lachesi esaten dio arimaren tinkotasuna ederra dela gogoetarekin batera gertatzen denean, baina ez dela ederra gogoetarik gabe gertatzen zenean. Sokratesek Lachesi galdetzen dio ea gogoetan oinarritutako tinkotasun oro adoretsua den; Lachesek ezetz erantzuten dio, batzuetan jakindurian oinarritutako tinkotasuna ez dela ezjakintasunean oinarritutakoa baino adoretsuagoa. Orduan Sokratesek gogoetaren eta tinkotasunaren arteko harremanaz lehen esandakoa oroitarazten dio Lachesi. Elkarrizketaren amaieran Sokratesek esaten du ez dutela oraindik adorearen definiziorik lortu, baina bai haren bi eredu: Laches eta Sokrates. Sokratesek esaten du ez berak ez besteek dakitela adorea zer den. Ezjakintasun hori onartzeak bihurtzen du Sokrates adorearen eredu (Platon K.a. 399-385; Miller 2005).

Platonen Errepublika elkarrizketan beldur izan behar zaionari buruzko ezagutza zuzentzat hartzen da adorea eta hari buruzko ezjakintasun motatzat hartzen da koldarkeria. Sufrikario, atsegin eta beldurraren gisako emozioak jasan arren, arrazoibide zuzenari eusteko pertsona adoretsuak duen gaitasuntzat hartzen du adorea. Atseginaren nagusitasunarekin lotutako kasuak ezjakintasun kasutzat interpretatzen ditu. Epe laburrera jasotzen duten atsegina epe luzera jasotakoa baino handiagoa dela pentsatzen dute ezjakinek; ezagutzaren bidez gaindi dezakete uste oker hori. Epe luzeko eta epe laburreko atseginak eta minak ongi neurtzen dituztenek beren ezagutzaren arabera jo- 
katzen dute; epe laburreko atseginaren aldeko aukera egiten dutenek ezagutza-arazoa dute, atseginak eta itxurak edo irudipenak iruzurtzen baitituzte (Wilburn 2015).

Legeak liburuan Platonek planteatzen du gerra bat gertatzen dela norberaren baitan, norberaren kontra; Platonentzat, nork bere buruaren gain lortutako garaipena da garaipen guztietatik loriatsuena. Adorea nork bere beldurrari aurre egitearekin eta nork bere burua gidatzearekin erlazionatzen du. Platonek koherentziaren printzipioa aipatzen du Gorgiasen (Platon K.a. 389385). Koherentzia ez da lotzen aurrez finkaturiko arau batzuen arabera jokatzearekin, norbere buruarekin ados egotearekin baizik; pertsona koherentea bere buruarekin ados dagoena da. Norbaitekin desados egotekotan, hobe da besteekin ados ez egotea eta norberarekin ados egotea, norberarekin ados ez egotea eta besteekin ados egotea baino. Izan ere, pertsonek beren buruarekin harreman etengabean egon behar dute eta gaizki jokatzen dutenek gaizkilearekin harreman estuan jarraitu beste erremediorik ez dute. Beraz, Sokrates eta Platonentzat morala ez dute kanpoko arauek edo ohiturek definitzen, norberaren buruarekiko harremanak baizik.

\subsection{Adorea Aristotelesen arabera}

Sokratesek ez du adorearen definiziorik ematen, baina Aristotelesek bai: bertutetzat hartzen du adorea Etika Nikomakori liburuan (Aristoteles K.a. 350). Aristotelesentzat beldurra eta konfiantza inplikatzen duten egoeretan modu egokian jokatzeko disposizioa da adorea; alegia, koldarkeriaren eta ausarkeriaren artean arrazionalki determinaturiko bitarteko gunea (López et al. 2003).

Halere, Aristotelesek atzerapauso bat eman zuen eta zentzu hertsian landu zuen adorearen gaia (Zavaliy eta Aristidou 2014): eremu etiko eta politikotik atera eta gerraren eremura eta eremu fisikora mugatu zuen berriro ere. Adorea ekintzarekin erlazionatu zuen, ez ezagutzarekin. Aristotelesentzat adore militarra dago lehen planoan; gerran ari den soldadua da adorearen eredurik onena; gudu-zelaian gudariak sentitzen duen adoreak badu zerbait berezia Aristotelesentzat, heriotza-arriskua dakarten beste egoera batzuetako adoreek ez dutena (Miller 2005). Aristotelesek gudu-zelaiko adoreaz eta beste bertute sail batez eztabaidatzen du Etika Nikomakori liburuan: adorerik ez dio egozten gaixotasunez edo itota hiltzeko arriskua duenari; gudu-zelaian nobleki hiltzeko arriskua duenari egozten dio adorea. Heriotza-arriskuari ausardiaz egiten dio aurre gizon adoretsuak. Aristotelesek $\alpha v \delta \rho \varepsilon i ́ \alpha$ terminoa darabil adorea adierazteko; gizon gerlariari dagokion adorea da $\alpha v \delta \rho \varepsilon i ́ \alpha$ (Rosen eta Sluiter 2003). Aristotelesentzat, irudi adoretsuaren paradigma gerlaria da, ez filosofoa. Ohorezko heriotza bati beldurrik gabe aurre egiten diona da pertsona adoretsua. Aristotelesentzat, pertsona adoretsuak beldurrik gabe eta 
konfiantzaz aurre egiten die heriotza ekar dezaketen gudu-zelaietako arriskuei.

Etika Nikomakori liburuan adorea muturreko bi ertzen arteko erdibidean kokatzen du Aristotelesek: ertz batean beldurrik adierazten ez duten eta ausartegiak diren pertsonak daude; beste ertzean, beldur gehiegi duten koldarrak. Ezeri beldurrik ez diotenak alde batean eta beldur gehiegi dutenak beste aldean. Gehiegi eta gutxiegi, biak dira txarrak. Ezeri beldurrik ez izatearen eta guztiari beldur izatearen artean dago adorea. Bertute moralak ertzen arteko urrezko erdibidean kokatzen dira (Pears 2004).

Aristotelesentzat ongi jokatzeko beharrezkoa da nola jokatu jakitea, baina ez da nahikoa. Adoreak ezagutza teorikoa eta esperientzia praktikoa eskatzen ditu. Pertsona adoretsuak ez dira batere beldurrik sentitzen ez dutenak; pertsona adoretsuek ere beldurra diete giza indarrak gainditzen dituzten egoerei, baina, beldurrak beldur, beren sentimenduen eta gogoeten jabe dira eta arrazoiak eskatzen duen moduan jokatzeko gai dira. Ezagutzatik datorkie konfiantza eta arrazoiaren bidea erabiliz gainditzen dute beldurra. Aitzitik, ongia ezagutzearen eta ongia egitearen artean borondatea eta pasioa sartzen dira. Ezagutza praktikoa finkotasunik gabeko egoeren edo abagune egokiaren ezagutza da, bizitzan eta esperientzian oinarritua. Helburu noble bat lortzeko, abagune egokian arriskuei aurre egitea eskatzen du adoreak. Ez dago adore idealik; zirkunstantziak eta patua baliatu behar ditu adoreak; ziurtasunik gabeko egoeretan erakutsi behar da adorea. Aristotelesen arabera, grekoen kairos hitzak abagunearekin loturiko printzipio etikoa adierazten du: aldaketarako aukera ematen duen une kritiko iheskorra da kairosa (Berns et al. 2010).

Aristotelesek adorea gudu-zelaira mugatu zuenean, adorearen definizioaren hedadura mugatu zuen. Lachesen edonor izan zitekeen pertsona adoretsua, baina Aristotelesentzat bertute noble bat zen adorea. Hala ere, Aristotelesek aldarrikatzen zuen adorearen nobletasuna ez zen orbanik gabea. Pertsona adoretsuak heriotza nobleari aurre egin behar zion, baina, herri batzuek, hala nola espartarrek, koldarkeriari heriotzari baino beldur gehiago zioten. Lurralde horietako hiritarrek adoreari garrantzi handia ematen zioten eta borroka egitera behartuak zeuden; borrokarik egin ezean lotsagarriak izango zirela eta ohorerik ez zutela izango pentsatzen zuten. Aristotelesek esaten zuen heriotzari beti izan behar zitzaiola beldurra eta inor ez zela koldartzat hartu behar heriotzari beldurra ziolako. Ez zuen begi onez ikusten hiritarrak adore fisikoan gehiegi trebatzea.

\section{Adorea Erdi Aroko filosofian}

Grezia klasikoko filosofiak eta kristauen moralak albora utzi zuten gerlariaren adorearen eredua. Nork bere burua arrazoizko printzipio moralez gida- 
tzearen garrantzia azpimarratu zuten. Filosofoek, giza ekintzak gidatu behar zituzten printzipio moralak ezarri zituzten, baina ez zuten lortu printzipio horien arabera pertsonen jokaera aldatzea.

\subsection{Agustin Hiponakoa}

Grekoentzat morala politikan gauzatzen zen eta ideala lortzera zuzendua zegoen. Aldiz, pentsalari kristauek azterketa-objektu bihurtu zuten gizakia eta hura ikertzen saiatu ziren; pertsonaren barne-gatazkak, barneko joerak, sentimenduak eta bizioak aztertu zituzten. Agustinek Aitorkizunak liburuan esaten du Jainkoak bere buruaren aurrean jarri duela, zenbateraino den ahula ikus dezan eta barneko gaiztakerien berri izan dezan. Gizakia hutsegitez eta grinaz betetako izaki moduan ikusten du eta ezin du lortu idealaren mailarik edo zeruko aitaren perfekziorik.

Grekoek ez zioten balio handirik ematen lanari; lana ez zen jende aurrean erakusteko moduko zerbait. Aldiz, kristauek positibotzat zituzten lana, iraunkortasuna, nekea eta ahalegina; gizakiak ahalegin neketsua eta iraunkorra egin behar izaten zuen erabakiak hartzeko eta erabakitakoa betetzeko. Adoreak ongia egiten jarraitzeko indarra adierazten zuen. Intentzioarekin, erabakimenarekin eta borondatearekin erlazionatua zegoen adorea, eta ez ekintza fisiko soilarekin. Batzuetan pertsonaren borondateak ez zuen aski indar izaten adorea hauspotzeko eta nekeari aurre egiteko. Izan ere, pertsona adoretsuak borondatearen ahaleginaren kontrako indar bati aurre egin behar zion; indar hori batzuetan barnetik eta besteetan kanpotik etortzen zen; borondatearen zati batek nahi zuena beste zati batek ez zuen nahi izaten (Berns et al. 2010).

Pentsalari kristauek lanari lotuta eta azediatik edo tristura depresibotik abiatuta ulertzen zuten adorea. Azediak axolagabekeria, nagikeria, laxokeria, malenkonia eta depresioa adierazten zituen; malenkoniaren moduko zerbait zen azedia, eta zazpi bekatu kapitalen tradizioan kokatua zegoen, tristurarekin batera. Adorea, berriz, azediaren, nagikeriaren eta borondatearen biguntasunaren kontrako baliotzat hartzen zen (Berns et al. 2010). Pertsona adoretsua gaizkia borrokatzen ahalegintzen zen, ideala bilatzen baino gehiago; koldarkeriari ihes egiten saiatzen zen, adorea bilatzen baino gehiago; nahiago zuen sufrikarioa jasateko gaitasuna erakutsi, ongia bilatu baino. Moralaren ikuskera negatiboa bat zetorren kristauek zuten adorearen ikuskera negatiboarekin. Ondorioz, kristauen morala apaltasunaren etika zen: besteen begiradari ihes egiten zion eta agirian gauzatzen ziren bertuteak kritikatzen zituen; pertsona adoretsua ez zen besteengandik agertoki publikoan bereizten; barneko jarrera intimoak interesatzen zitzaizkion. Horrela, Elizaren Gurasoek printzipio hauen arabera antolatu nahi zuten elkarbizitza: apaltasuna eta nork bere buruari uko egitea. 
Agustinen jarraitzaileek ez zuten sinesten gatazketatik sortutako boterean, beldurra zioten desordenari eta zatiketari, pentsatzen zuten anabasak ez zuela politikarekin zerikusirik, eta ezin zuten onartu ordena eta boterea sor zitezkeenik desordena besterik ez zegoen lekuan. Politika eta bertutea gogoeta teorikotik eta adostasunetik zetozela pentsatzen zuten.

\subsection{Tomas Akinokoa}

Aristotelesen eragin handia jaso zuen Tomas Akinokoak, eta bertute garrantzitsutzat zeukan adorea. Pertsona adoretsua zaurgarria zen, zauritua izateko arriskua onartu behar baitzuen; min hartzeko eta martiri bihurtzeko prest ez zegoena ezin zitekeen adoretsua izan. Tomas Akinokoak adorearen baitan bereizi egiten zituen ekintza adoretsua eta nork bere bizitza zaintzea. Pertsona adoretsuak heriotzaren aurrean erakusten zuen adorea, baina adoreak ezagutza eskatzen zuen eta pertsona adoretsuak ez zituen arriskuak itsuitsuan hartzen; arriskuei buruzko jakinduriak adorearen mugarriak finkatzen zituen. Tomas Akinokoarentzat norberaren bizitza galtzearen kontra zegoen adorea; ez zuen defendatzen norberaren bizitza zaintzeari begiratzen ez zion adorerik (Ruda 2017).

Pertsonek, batzuetan, beldurra sentitzen zuten helburu bat lortu behar zutenean eta beldurraren eraginez uko egin ziezaioketen helburuak lortzeari. Beldurrak deseroso sentiarazten zituen eta, haren eraginez, arrazoiz jokatzeari uzten zioten. Beldur hori arinduko zuen bertutea adorea zen Tomas Akinokoarentzat. Haren iritziz, pertsona adoretsuak bere bizitza zentzurik gabe arriskuan jartzen ez bazuen ere, prest egoten zen arriskuak hartzeko; osterantzean, bizitza gauza bihurtzen zuen, eta objektu bihurtutako bizitzak ez zuen zentzurik. Bere bizitzari atxikimendu handiegia izateak adore-gabeziara eramaten zuen, eta horrelako atxikimendua gaixotasuna zen. Adore-gabezia gaixotasuna zen Tomasentzat (Berns et al. 2010).

Egoera larriek sentiarazten diguten beldurra gainditzeko adorea behar dugu. Adorea behar dugu, baita ere, zirkunstantzia beldurgarriei aurre egiteko. Adoreari esker aurre egiten diegu gehiegizko beldurrari eta arrazoirik gabeko ausarkeriari. Tomas Akinokoarentzat, benetako bizitzaren izenean bere bizitza sakrifikatzeko prest zegoen edonor izan zitekeen adoretsua. Aitzitik, betiko bizitzaren sinesmena eta itxaropena zituenak bakarrik sakrifika zezakeen bere ziurtasuna. Tomas Akinokoaren iritziz, adore-ekintza bakardadean egiten zen eta norberaren burua bakarrik ukitzen zuen; horrela, bizitzako gertaerarik bakartiena eta adore gehien eskatzen zuena heriotza zen. Adorea zuenak gauzak gerta zitezen uzten zuen; bere buruaren babesa eta ziurtasun mota guztiak albora uzten zituen. Pertsona adoretsuek honako bereizgarri hauek behar zituzten arriskuei, minari, sufrikarioei eta heriotzari aurre egiteko: erresistentziarako gaitasuna, konfiantza, itxaropena, nobleta- 
suna, pazientzia, iraunkortasuna eta goi-mailako asmoak (Ruda 2017; Tomas Akinokoa 1265-1274).

Tomas Akinokoarentzat, goi-mailako helburuaren lorpena mehatxatzen zuten oztopoak baztertzen zituen gogoaren indarra zen adorea; jakinduria, justizia eta neurritasunarekin elkartua zegoen. Adorea jakinduriarekin elkartzen zenean, norberaren buruarekiko neurritasuna eta besteekiko justizia agertzen ziren. Tomasentzat, adorea beste bertuteen oinarrizko baldintza zen eta fede, itxaropen eta errukiarekin elkartuta bakarrik agertzen zen. Tomas Akinokoak adimena eta borondatea tirabiran ikusten zituen. Jakinduria nagusitzen zenean, adimenaren indarrak arrazoiari obeditzen zion. Borondatea nagusitzen zenean, gidaririk gabeko egoskorkeria nagusitzen zen. Tomasentzat, adoreak ahalbidetzen zuen borondateak arrazoiari jarraitzea; iraunkortasunarekin eta tinkotasunarekin erlazionatzen zuen adorea, erasoarekin eta borrokarekin baino gehiago (Tomas Akinokoa 1265-1274).

\section{Aro Modernoko adorea}

Aro Modernoko filosofoen iritziz, adorea herri ezjakinen eta basatien bertutea zen. Antzinateko gizarteak zibilizatu gabeak ziren eta honako bereizgarri hauek zituzten: ausardia handia, konkista-espiritua, malgutasun gutxi eta ohitura basatiak. Aro Modernoan desagertu egin zen adoreari eta moral transzendenteari buruzko diskurtsoa; adoreak utzi egin zion bertute nagusi izateari eta beldurra eta interesa bihurtu ziren Aro Modernoko eraikuntza moralaren zutabe. Interesen gain oinarrituta antolatu behar zen gizartea, eta gizakien interesetan oinarrituta lortu behar zen adostasun soziala. Gizarte zibilizatuak interesaren eta merkataritzaren gain oinarritzen ziren, interesek baketsu eta atsegin bihurtzen baitzuten jendea. Antolamendu politikorako arriskutsuak ziren behartsuak eta interesik gabeak, tratuetara heltzen ez zirelako. Interesak partekatzeak aukera ematen zuen herritarren grinak eta pasioak erregulatzeko (Berns et al. 2010).

Kontzientziaren eta koldarkeriaren arteko harremanak aztertzeko asmoz, Ediporen eta Hamleten irudiak baliatu zituen Freudek. Horrela, gizateriaren bi garai bereizi zituen:

1. Historiaren hasieran jainkoek mugitzen zuten gizaki heroikoaren eredua zen Edipo: muga guztiak eta lege guztiak hausteko prest zegoen. Edipok, gogoetarik egin gabe eta orakuluak esandakoari jaramonik egin gabe, aita hil zuen eta amaren ondoan haren lekua hartu zuen.

2. Aro Modernoan errepresioa nagusitu zen eta zalantzaz beteriko gizaki ahula agertu zen. Pentsamenduaren sareetan harrapatua gelditu zen, mitologia heroikoari uko egin zion eta koldarkeria nagusitu zen hartaz. Kontzientziaren izenean bere bulkadak erreprimitu zituen gi- 
zaki modernoa sinbolizatzen zuen Hamletek; aitaren hiltzailearen eta amaren maitalearen irudian bere desira ezagutu zuen, baina desira hori erreprimitu egin zuen. Hamletek ikusi zuen aita erail egin zutela eta osabak haren lekua hartu zuela, baina ez zuen mendekua hartzeko adorerik izan; mendekua hartzea geroaren gerorako utzi zuen. Horrela, erabakimenik eta borondaterik gabeko ereduaren paradigma bihurtu zen Hamlet: kontzientziak koldar bihurtu zuen pertsona. Freuden iritzian, gehiegizko jarduera intelektualak paralizatu zuen Hamleten energia aktiboa (Freud 1900).

Hobbesek Leviathan liburuan esaten zuenaren ikuspegitik, beldurrak ekintza arrazionalak sustatzen zituen eta zibilizazioa indartzen zuen. Beldurra partekatzeak boterea eraikitzera bultzatzen zituen gizakiak; beldurra estatuaren sorreraren oinarrian zegoen, arrazionaltasuna sendotzen zuelako eta itun soziala sustatzen zuelako. Beldurrak estatuaren beharra arrazoibidez justifikatzen zuen eta zibilizazioa indartzen zuen. Gizakiak bere interesen eta bere beldurren araberako kalkuluak egiten zituen.

\subsection{Makiavelo (1622)}

Ikusi dugun moduan, Aristotelesek gabeziaren eta gehiegikeriaren, ausarkeriaren eta koldarkeriaren arteko erdibidean kokatzen zuen adorearen bertutea. Makiavelori, ordea, ez zitzaizkion erdibideak gustatzen. Gogor kritikatzen zuen Aristotelesen teoria hori: pentsatzen zuen erdibidearen oreka bilatzen zuenak gatazkarik gabeko boterea eta desabantailarik gabeko abantaila nahi zituela; esaten zuen erdibidera jotzen zuenak lagunik ez zuela egiten eta etsairik ez zuela desagerrarazten; harentzat azkenekoa zen neutraltasunean babestea; ez zegoen ados erdibide justuaren tradizio grekoarekin. Negargarria iruditzen zitzaion Espartaren eta Erromaren abantailak konbinatzea; esaten zuen Erromatarrek ere erdibideari ihes egin ziotela. Makiavelorentzat, bertutea gehiegikerian oinarritzen zen eta gabezian zegoenak erdibidea aukeratzen zuen. Esan beharra dago, Makiavelok Aristotelesen erdibidea kritikatu zuenean, haren interpretazio murriztailea egin zuela, ez baitzuen kontuan hartu Aristotelesen erdibidea ez zela beti berdina.

Makiavelok bi hiri mota bereizten zituen:

1. Espartako hiri txiki aristokratikoa, legelariaren arrazoiaren aginduetara funtzionatzen zuena. Hango eredu filosofikoa gizabanakoan oinarritua zegoen eta gizon bakar baten arrazoiak finkatzen zituen han legeak; muga itxiak zituen eta egonkortasuna eta batasuna ziren han nagusi.

2. Erromako hiri politikoa gertaeren eta desadostasunen ondorioz aldatzen zen eta hango legea ez zegoen hasieratik finkatua. Erromatarrek 
ez zuten beren lurraldea arrazoimenaren arabera antolatu, borroka eta entsegu ugariren bidez baizik.

Makiavelok arrazoiaren lehentasuna baztertu zuen. Erroma ez zuen gizabanako baten adimenak taxutu, jende askoren adimenak baizik; belaunaldi askotako jendearen lanaren emaitza izan zen. Adorea eta bertutea maila kolektiboan gauzatu ziren han. Erromaren arrakasta politiko eta militarra hiritarren erabaki kolektibo eta anonimoen emaitza izan zen eta ez banakoena (Berns et al. 2010). Ciceron ere aldendu egin zen Sokrates eta Platonengandik, haiek irudimenezko hiri batean pentsatzen zutelako. Ciceronek ez zuen hiriaren irudimenezko errepresentazio bat egin nahi; denboran zehar hedatutako konstituzioa nahi zuen, ez kolpe batez ezarritako konstituzioa (Berns et al. 2010).

Makiavelok zuzenki eraso zion Agustinen Jainkoaren Hiriari. Machiaveloren iritziz, Erromak zutik iraun zuen paganoek beren jainkoei sakrifizioak eskaintzen zizkieten bitartean, baina gainbehera etorri zen erlijio kristaua praktikatzen zutenak agintzen hasi zirenean. Erromako erlijioak eta kristautasunak modu ezberdinean jokatu zuten: paganoak harro, lehiakor eta menderatzaile agertzen ziren; kristauak, berriz, apal, esaneko eta maitekor agertzen ziren. Laudorio-goseak eta loriaren grinak eraman zituzten erromatarrak gauza harrigarriak egitera; beste pertsonen oroitzapenean iraun nahi zuten. Agustinentzat, aldiz, benetako loria ez zetorren beste gizakien onarpenetik, Jainkoaren borondate eta graziatik baizik; Jainkoak harroei eraso egiten zien eta apalak babesten zituen. Agustinentzat, erromatarren neurrigabeko harrokeriak eta loria-gose aseezinak ekarri zuten Erromaren erorketa; Erromako gatazkak konpontzeko Probidentziak eskuhartu behar izan zuen. Aldiz, Makiavelo indarraren, boterearen eta harrotasunaren alde agertu zen. Haren iritziz, Erromako gatazkak askatasunean ebatzi behar ziren. Kristauak izan ziren beren apaltasunarekin Erroma ahuldu zutenak; sufrikarioa gainditzen irakatsi ordez, sufrikarioa jasaten irakatsi zuten; jendea politikatik eta agoratik erretiratu eta elizetan babestu zuten (Berns et al. 2010).

Makiavelok historiako gertaerekin, denborarekin eta abagunearekin erlazionatua ikusten zuen adorea; bazegoen denboran zehar harremanak josteko modu adoretsu bat. Makiavelorentzat, gertaera batzuk, zoritxarrekoak ere bai, aurrez abisatu gabe agertzen ziren, eta gizakiak zoritxar-garaietan handitasunez eta bertutez jokatzera deituak zeuden. Makiavelok suhartasuna, bizkortasuna eta ausardia defendatzen zituen; baztertu egiten zituen koldarkeria, epeltasuna eta zuhurtzia; baztertu egiten zituen aurrez definitutako soluziobide teorikoak, ez zutelako arazoak konpontzeko balio (Berns et al. 2010).

Makiavelorentzat, adorea ezagutza mota bat zen, baina ez gertaerak objektu bihurtzen zituen ezagutza, baizik eta abagunea baliatzen zuena, gatazkaren beharra zuena edo gatazkari ihes egiten ez ziona. Ezagutzak ez 
zuen gatazkaren eta hauskortasunaren beldurrik eduki behar; ezagutzaren bidez abagunea kontrolatu nahi zenean, ihes egiten zuen abaguneak. Pertsona adoretsuak gatazka- eta hauskortasun-egoerei beldurrik gabe aurre egiten zien; boterea zatiketarekin eta ezegonkortasunarekin erlazionatua zegoela onartzen zuen; denboran ekinez, abagunea aprobetxatzen zuen (Berns et al. 2010).

Printzea liburuan Makiavelok esaten zuen handitasuna ez zetorrela ongiaren aldetik bakarrik; gaizkiak ere bazuela distirarik eta handitasunik. Esaten zuen politikan efektuen logikari begiratu behar zitzaiola; efektuen logikaz gaizkia eta ongia balia zitezkeela. Gaizkiaren erabileraren adibide moduan Mazedoniako Felipek erabilitako bitarteko ankerrak deskribatu zituen. Esaten zuen ongiaren edo gaizkiaren bideak jarraitu behar zirela, eta ez erdibidea.

\subsection{Spinoza}

Spinozarentzat, adorea ez zuen adierazten heriotzaren aurrean bere burua sakrifikatzen zuenak; bere burua eta besteak maitatuz, eskuzabaltasunez eta tinkotasunez zoriontsu bizi zenak agertzen zuen adorea. Eskuzabala zen neurrian, ahaleginak egiten zituen arrazoiaren aginduen arabera beste gizakiei laguntzeko eta laguntasun-loturei eusteko. Spinozarentzat, maitasunak gorrotoari irabazi egiten zion eta ekintzetan agertzen zen maitasuna. Bizitzaz egiten zuen gogoeta, ez heriotzaz; bere portaera ez zuen beldurrak gidatzen. Beretzat nahi zuen horixe nahi izaten zuen besteentzat ere: ongi bizitzea, ekitea, bere izaera kontserbatzea. Gizon aske eta adoretsua bizitzaz eta energiaz beterik zegoen, eta arrazoiaren aholkuak jarraitzen zituen. Tinkoa zen eta ahaleginak egiten zituen bere izaera arrazoiaren aginduen arabera kontserbatzeko.

Spinozarentzat, pertsona adoretsuak ez zuen gizakiaz gaindikoa onartzen eta bere bizitza mespretxatzen; halako portaerak gizaki bakartu eta pasiboenak ziren. Ez zituen portaera adoretsutzat hartzen Sokratesen eta Kristoren agoniak. Etsi egin zuen inor ezin zitekeen adorearen eredutzat hartu, ezin zelako besteentzat baliagarria izan agonian deuseztatzen ari baldin bazen.

Étienne de la Boétiek Discours de la servitude volontaire liburuan (1576/1993) esaten zuenaren arabera, mirabetza ez zetorren mendekotasunetik bakarrik; mirabetza onartzen zutenen borondateak edo borondate-gabeziak ere bazuen zerikusia. Gizaki asko uztarpean zeuden, baina ez indar handiagoko norbaitek derrigortzen zituelako, baizik eta haren mendean liluratuak zeudelako. Beraz, mirabetzatik irteteko ez zen nahikoa edo ezinbestekoa menderatzailearen boterea suntsitzea; jokoan zegoena, askatasunez bizi nahi izatea eta libre izateari muzin egitea zen. Gizakiak bazuen, beraz, erantzukizuna bere mirabetza-egoerari zegokionez; mirabetza onartu ala ez era- 
baki behar zuen. Mirabetza ez onartzea erabakitzen bazuen, arrazoia erabil zezakeen aldaketari ateak irekitzeko (Berns et al. 2010).

\subsection{Kant}

Erdi Aroko gizakiak babes-egoeran eta mirabetzan bizitzen jarraitu nahi izan zuen; ez zuen adimena erabili egoera aldatzeko, ez baitzuen horretarako adorerik. Babes-egoeran egotearen ardura gizakiarena berarena zen neurri handi batean; arazoa ez zen gertatzen adimen gutxiegi zuelako, baizik eta erabakimen eta adore gutxi zuelako. Aldiz, Ilustrazioko gizakia bere babesegoeratik irten zen. Gauzak jakiteko eta adimena erabiltzeko adorea baliatzea erabaki zuen (Berns et al. 2010; Kant 1784/1991).

Bere kabuz pentsatzen hasteko eskatu zion Kantek gizakiari. Adimena erabiltzeko gizakiak behar zuen adoreaz hitz egin zuen; esaten zuen adorerik ez zuenak ezin zituela erabili bere baliabide arrazionalak eta ezin zuela jokatu benetan zegokion moduan. Espazio publikoko babesleetatik askatu nahi izan zuen pentsamendua. Beldurrak eta nagikeriak geldiarazitako adimenari aurre eginez, arrazoia erabiltzearen aldeko apustua egin zuen Kantek: Sapere aude (ausart zaitez jakitera). Gogoeta ez zuten kanpoko printzipioek edo arau objektiboek gidatu behar; bere kabuz pentsatzera ausartu behar zuen eta horretarako printzipio subjektiboak baliatu behar zituen. Critique de la faculté de juger liburuan (Kant 1790/2000), bere kabuz pentsatzeko gai zen arrazoimen aske, aktibo eta autonomoa aldarrikatu zuen. Harentzat pentsamendua ez zen jarduera teoriko bat, arrazoia erabiltzeko modu praktiko bat baizik (Jeanmart eta Blésin 2009).

Kantentzat, hiritarrak askatasunez egin behar zuen gogoeta gizarteko kide guztien arazoez. Gogoeta egiteko bestearen lekuan jartzen zen, baldintza subjektiboen mugei ihes egiteko; arrazoitzeko eta gertaerak errepresentatzeko modu komuna eskuratu nahi zuen. Kanten iritziz, mundua aldatzeko aukerak barne-herstura eragiten zien pertsonei, ikusten baitzuten ez zela ezinbestekoa mundua zen bezalakoa izatea. Arrazoiaren erabilera askeak indeterminazio-egoeran kokatzen zuen arrazoia, eta egoera horrek barneherstura sortzen zuen. Kantek barne-hersturaren gaia filosofian sartu zuen, baina barne-herstura sortzen zuena ez zen beste objektuen moduko objektu bat, uki edo ikus zitekeena. Heideggerrek (2008) honela azaltzen zuen barnehersturaren objektua: beldurrak objektu konkretu bat dauka munduan eta barne-hersturak ez dauka objekturik; barne-herstura definitu gabeko objektu baten beldurra da; gure gogamenak sortutako mamu baten beldurra da. Lacanek (2004) aldaketa bat sartu zuen barne-hersturaren interpretazioan: esan zuen barne-hersturak ez daukala munduan objekturik, baina hala ere ez dela objekturik gabea; haren objektua pasatzen edo gertatzen ari den objektua, objektu iragankorra dela; gertakizun bat dela (Ruda 2017). 


\section{Aro Garaikidea}

Aro Garaikidean ere adorearen gaia egoera, aktore eta testuinguru berezietan bakarrik agertzen da. Desagertu egin dira gizaki guztientzat balio zuten arauak; irizpide, arau eta printzipioak testuinguru batean bakarrik dira baliagarriak; edozein unetan eztabaidatu eta zalantzan jar litezke. Gizarte garaikideko kideei etengabeko ardura eskatzen zaie eta eskaera horri emandako erantzunaren arabera neurtzen dituzte beren buruak.

Gizarte garaikidean, industriaurreko arotik industriaren arora iragan gara; adore indibidualaren kontzepzio klasikotik adorearen dimentsio kolektibo eta anonimora iragan gara. Automatizazioak langileen lana erraztu du, baina zaildu egin du langile guztiei lanpostu bat bermatu ahal izatea. Teknozientziaren garai honetan makinek tokia kendu diote gizakiari, aldaketa genetikoak gertatu dira, baliabide naturalak agortzen joan dira, klima-aldaketa arriskutsuak eta katastrofe sozialak gertatu dira. Zientzia eta teknologiaren garapen bizkorrak eragin dituen arriskuen aurrean gizarteak gogoeta egin du eta ikusi du estrategia kolektibo berriak behar direla krisi-egoerari aurre egiteko. Etikaren eraldaketa ezinbesteko bihurtu da: ondorio zuzenen eta egozgarrien arduradun izatetik gizateriaren etorkizunaren arduradun izatera iragan behar du gizakiak (Berns et al. 2010).

\subsection{Nietzscheren heroia}

Homeroren heroien balio moralak aldarrikatu zituen Nietzschek: indarra, adorea, noblezia, ohorea, begirunea eta handitasuna. Nietzscheren heroia ohorezko eta prestigiozko lerro genealogikoan kokatua zegoen; beste gizaki hilkorren gainetik nabarmentzen zen, haiek ez bezalako balentriak egin zituelako gerraren edo aurkikuntzen arloan; bere minak eta ongizatea ahazten eta gutxiesten zituen, nahiz eta sufrikario latzak jasana eta eragina izan (Marty 2011).

Nietzschek goi-mailako eta behe-mailako gizakiak bereizten zituen: goimailako gizaki baten existentziak justifika zezakeen behe-mailako milaka gizakiren existentzia; ongi ikusten zuen gizaki bikainak garatzeko behe-mailakoak sakrifikatzea. Nietzscheren heroia erdipurdiko pertsonen gainetik nabarmentzen eta boterearen erpinera igotzen saiatzen zen. Moral aristokratikoa gerratik sortzen zen: heroiak bere balentrien bidez balio-sistema bat sortzen zuen, herriaren gidari bihurtzen zen eta bere legea eta morala ezartzen zizkien masei. Onarpenaren beharrik ez zuen balio-kode bat sortu eta ezartzen zuen heroi aristokratikoak; horrela lortzen zuen heriotzaren ondorengo existentzia ziurtatuko zion ospea. Goi-mailako zibilizazioaren oinarrian ankerkeria zegoen, espezie guztietatik ankerrena gizakiena baitzen. Pertsona ankerrak atsegin hartzen zuen sufrikariotik; sufrikarioak bazuen toki 
bat Nietzscheren heroiarengan. Heroiaren muinean zeuden mina sentitzeko eta mina eragiteko indarra; sufrikariora ohituak zeuden heroiek besteei ezartzen zieten beraiek bizi zutena (Marty 2011; Nietzsche 1898).

Bere burua eta bere grinak (haserrea, beldurra, likiskeria, mendekua, esperantza, etsipena, ankerkeria) kontrolatu behar zituen Nietzscheren heroiak. Heroiak sarritan agertzen zuen bere pasioak bat-batean asebetetzeko joera; ez zekien itxaroten. Itxaroten ikasteko, gogoeta egiten eta grinen asebetetzea gerorako uzten ikasi behar zuen; horrela, denbora luzez pasioen indarra pilatu behar zuen, askatu aurretik. Mendeetan pilatutako indarrak bereganatu eta une egokiaren (kairosaren) zain egon behar zuen; pasioak deskargatzeko une egokia aukeratu behar zuen. Heroia izan nahi zuenak, gaizkileek ez bezala, bazekien grinak askatzeko une egokia aukeratzen (Marty 2011).

Nietzschek nagusiaren morala eta esklaboarena bereizi zituen eta nagusiaren moralaren alde egin zuen, moral hori bizitzaren balioetan oinarritzen zelako. Esklaboek bertute bihurtzen zituzten beren ahultasunak; apaltasuna, mendekotasuna eta txirotasuna goratzen zituzten, benetako bertuteak balira bezala. Nietzscheren iritzian, esklaboaren morala erresuminean oinarritzen zen eta ezintasun politikoa konpentsatzen saiatzen zen (Nietzsche 1900). Schopenhauerrek defendatzen zuen errukia altruista zela eta moralitatearen iturburua zela; baina estoikoek, Spinozak eta Nietzschek pentsatzen zuten errukiak ahultasuna adierazten zuela eta errukiaren objektu zirenak babespera kondenatzen zituela. Nietzscherentzat, botere-borondatea besteak kontrolatzean eta menderatzean zetzan; gizarte guztiek egiten zuten hori eta gizarte guztiek zuten hierarkia bat.

\subsection{Paul Tillich}

Tillichentzat (1952), adorea ulertzeko gizakiaren izaera ulertu behar da. Ez-izatearen, heriotzaren eta mugen kontzientziak sortzen dio barne-herstura ontologikoa gizakiari; barne-hersturak ezerezean du jatorria, ez du objekturik eta ezin zaio ihes egin. Barne-herstura eta beldurra ez dira gauza bera: beldurra objektu batek eragiten du; aldiz, barne-hersturak ez dauka objekturik. Munduak ez du ezinbestean den modukoa izan behar, eta ezinbestekotasunik ez dagoela ikusteak barne-herstura eta ezinegon sakona sortzen dizkio gizakiari (Badiou 2007).

Objektu baten beldurrean oinarritzen ez den barne-herstura barne-herstura biluzia edo ez-izatearen barne-herstura da; adoreak ezin izaten du barneherstura hori uxatu. Pertsona adoretsuak ez-izatea eta barne-herstura onartzen ditu; positibotasuna bilatzen du eta ez-izateari aurre egiten dio, bere identitatea baieztatuz eta berretsiz. Pertsona neurotikoek kontzienteki bizi dituzte barne-herstura eta ez-izatea, eta ezin izaten dute beren burua berretsi. Pertsona arruntak objektu bat seinalatzen dio barne-hersturari, eta barne- 
herstura beldur bihurtzen du. Horrela, ez-izateari buruzko kontzientzia galtzen du eta, barne-herstura beldur bihurtzean, beldurrari adorez aurre egin diezaioke.

Beldurra zaurgarritasuna hautematearekin erlazionatua dago: mehatxua zuzen ala oker hautemateak eragina du hark sor dezakeen beldurrean. Gizakiak pentsa dezake gertaera negatiboek bere baliabideak gaindituko dituztela edo bere baliabideei esker gertaera horiek gaindituko dituela; adoretsua denak gertaerei aurre egitea erabakiko du (Finfgeld 1995). Estresak gizakiari eragiten dizkion ondorioak biguntzen ditu erresilientziak; erresilientziari esker, gertaera estresatzaileak ebaluatzen ditu, haien mehatxua arintzen du eta bere burua gertaera haiei aurre egiteko prestatzen du (Florian et al. 1995).

Erresilientzia, benetakotasuna, adorea eta autonomia elkarrekin loturik daude. Benetako bizitza bizi nahi duenak ez du ez-izatea ukatu behar; izatea edozein unetan ez-izate bihur daitekeela onartzeak sortzen duen izua onartu behar du; ez-izatea onartzeak adorea eskatzen du. Tillich (1952) eta Mayren (1975) arabera, benetako bizitza bat bizitzeko gai den pertsona adoretsua da berez. Pertsona adoretsuak kontsistentzia eta adostasuna agertzen ditu barne-esperientzien eta kanpoko portaeraren artean; pertsona adoretsuaren portaera haren emozioen eta balioen isla da. Rogersentzat (1961), benetako nia garatzeko ezinbestekoa da gurasoen baldintzarik gabeko kontsiderazio positiboa; benetakotasuna eta autonomia beharrezkoak ditu gizakiak pertsona osoen gisara funtzionatzeko. Pertsona adoretsuek modu autonomoan jokatzen dute, beren rolak askeki aukeratzen eta barneratzen dituzte eta benetakoak eta asebeteak sentitzen dira (Ryff eta Keyes 1995; Sheldon et al. 1997). Mayren (1969) arabera, norbera den modukoa izatea eskatzen du autoaktualizazioak, eta norbera izateko adorea behar da. Maslowk (1970) dioenez, autoaktualizatzen diren pertsonek den moduan onartzen dute beren burua, eta benetakotasuna eta naturaltasuna darie. Larsen eta Gilesen (1976) arabera, pertsona adoretsuak bere aukerak egiten ditu, bere erabakiak hartzen ditu eta bere emozioak agertzen ditu, benetakotasunaren ikuspegitik. Benetakotasunak (Kernis eta Goldman 2006) nork bere buruaren alderdi guztiak ezagutzea eta norberari dagokion informazioa modu inpartzialean ebaluatzea eskatzen du.

\subsection{Munduarekiko beldurra eta adorea: Hannah Arendt}

Munduak ahalbidetzen du giza bizitza eta mundua da gizaki guztion espazio politikoa. Komunitate baten kide izateak munduaren ikuspegi bat ematen dio gizakiari, eta espazio politikoan ekintzaren bidez eskuhartzen $\mathrm{du}$; baina ekintzak adorea eskatzen du. Eremu politikoko bertute nagusia da adorea: pertsona adoretsua gehiago kezkatzen du askatasunak bizitza arruntak baino; adoreak askatu egiten ditu gizakiak bizitzako premien mendetik 
(Arendt 1972). Bizitza ez da ondasunik preziatuena; askatasunik gabe bizitzea ez du merezi. Askatasunaren esperientzia-eremuan gertatutako ekintza gatazkatsuek eta borrokek ematen diote zentzua bizitzari. Adoreari esker, adurrak ezarritako ezinbestekotasunari, bizitzarekiko atxikimenduari, hiltzeko beldurrari eta premiaren erreinuari ihes egin eta askatasunaren erreinuan sartzen da gizakia (Berns et al. 2010).

Arendtek adorea bizitza publikoaren zentroan jartzen du. Politika egiteko bi modu (politika ekoizpen moduan eta politika praxi moduan) bereizten ditu; ekoizpena eta praxia aurrez-aurre jartzen ditu. Platonek pentsamendu politikoaren ekoizpen imitatzaileari eman zion garrantzia; ekoizpen horrek bazuen egile bat, aurreikus zitekeena. Praxi politikoa, berriz, harremanen eta hizkuntzaren sarean txertatua zegoen eta ezin zen aurreikusi. Arendtek esaten du praxi politikoa ekoizpenera mugatzeak ekintza politikoaren galera ekartzen duela, tiraniari ateak irekitzen dizkiola, gobernu arrazional bat gauzatzen duela, ordena eta batasuna finkatzen dituela eta aniztasunaren berezko hauskortasuna ezabatzen duela. Arendtentzat, aurrez finkatutako elkarbizitza-ideia batera egokitzeak ez du balio; aniztasuna errespetatzeak ematen dio politikari eraginkortasuna. Gizakien aniztasuna da ekintzaren eta hitzaren oinarrizko baldintza; aniztasun horretan txertatzen dira berdintasuna eta bereizkuntza (Berns et al. 2010).

Arendtentzat, pertsona konprometituak askatasunez egiten dituen ekintzetan eta hitzetan agertzen da adorea. Pertsona adoretsuak bere babeslekua uzten du eta ekintza bidez argi publikora irteten da. Agertoki publiko batean agertzen den bertute politiko kolektibo moduan definitzen du adorea Arendtek. Alde batetik, espazio publikoko ekintza- eta hizkuntza-harremanen sarean txertatuta, legearen aurrean berdintasuna lortzen du. Beste aldetik, politikaren baldintza hauskorra den aniztasuna indartzen du, gizakien berezitasunak, ikuspegiak eta testuinguruak kontuan hartuta. Adoretsua izateko besteen aurrean mozorroa kendu eta bere burua agertu behar du gizakiak; ez du aldez aurretik erabakitzen eta kontrolatzen besteei agertuko diena; ez daki zer agertuko duen bere hitzen edo ekintzen bidez, besteen aurrean mozorroa kendutakoan. Ustekabekoei aurre egiteko prest egon behar du. Pertsona adoretsuak bere kontrola eta maisutasuna galtzea onartzen du. Ikuspegi horretatik, gizaki guztiak izan daitezke adoretsu; gizaki bakoitzaren baitan heroi bat gordetzen da (Arendt 1972).

Arendten arabera, ekintza determinatzen duena ez da gizakiak ekintzan jarritako intentzioa; ekintzak intentzioen mugak gainditu egiten ditu eskuarki. Ekintzailea borondate jakin eta mugatu batetik abiatu arren, zehaztu gabeko testuinguru anizkoitz batean kokatzen da eta hasieran finkaturiko mugak gainditu egiten ditu; beraz, ekintzaileak ez du aldez aurretik jakiten ekintzaren bidez abian jarritakoaren ibilbidea eta amaiera zein izango diren. Ekintzaren zentzua prozesuaren amaieran agertuko da. Ekintzaile adoretsuak 
bere intentzioaren tiraniari ihes egingo dio, eta aniztasunaren arriskuei erantzuteko prest egongo da (Arendt 1983).

Pertsona adoretsuak aurre egin behar dio ekintzak berezkoa duen iragarrezintasunari; onartu egin behar du bere ekintzek ihes egiten diotela eta hutsegiteko arriskua duela. Bertute politikoa ez da pertsona bakoitzaren konbentzimenduen ondorioa, maila kolektiboko eraginkortasunaren ondorioa baizik. Adorea duenak ez du atzera egiten aurreikus ezin daitezkeen ondorenen aurrean; besteekin batera erabakitako ekintzen ondorenak onartzen ditu, aurreikus ezinak izan arren. Gizaki aske eta adoretsuak ez du hartu behar jarrera teoriko eta kontenplatiboa; bere babeslekutik irten eta espazio publikoan ardura politikoa hartu behar du. Adorea eguneroko bizitzan txertatzen du Arendtek: elkarrekin eratutako munduari erantzun behar diote gizakiek. Gizaki guztiak heroi izan daitezke eta testuinguru anitzetan hainbat eratako heroiak bizi dira elkarrekin (Arendt 1983; Herzog 2004).

\subsection{Michel Foucault: egia esateko adorea (Foucault 2009)}

Egia ekoizten duen ekintza edo prozedura multzoa da aleturgia; ekintza horren bidez, gezurrezkoa, ezkutukoa, aurreikus ezin daitekeena edo ahantzitakoa gainditzen da eta egiazkoa dena ekoizten da. Nortasun etikoa eraiki eta norberaren burua ezagutu nahi duenak egia esateko eta onartzeko adorea izan behar du. Aleturgiaren bidez egia ekoizteko parresia praktikatu behar du, hots, ausarki hitz egin behar du; egia esan behar du mozorro, erreserba edo apaingarri erretorikorik gabe. Egia esatea edo parresia praktikatzea arriskutsu bihurtzen da parresiastarentzat (parresia praktikatzen duenarentzat), entzulearekin edo solaskidearekin duen lotura soziala apurtzera eraman baitezake. Parresiak adore bikoitza eskatzen du: hitz egiten duenarena eta entzuten duenarena; egia osoa esateko adorea eta egia mingarria onartzeko adorea. Helburu noble batzuengatik guztien kontra borrokatzen den parresiasta heriotza-arriskuan ere jar daiteke (Foucault 2009).

Zinismoaren eta parresiaren artean lotura handia ikusten du Foucaultek. Zinikoek parresia praktikatzen zuten eta bizitza arriskatzen zuten. Parresia praktikatzeko aukera ematen zuen bizimodua aukeratzen zuten. Bizimodua eta egia esatea elkarrekin estuki lotzen zituzten. Diogenesek oso ongi hezurmamitu zuen parresiastaren irudia: alferrikako ohiturak eta iritziak albora utzita, askatasun guztia zeukan egia esateko; bere bizimoduaren bidez egiaren testigantza ematen zuen eta egia haren gorputzean hezurmamitzen zen (Foucault 2009). Zinikoek bete-betean, modu basati eta eskandalagarrian, agertzen zuten egia. Gizartearen konbentzio, ohitura eta balioak apurtzen zituzten. Beste bizitza mota bat posible zela adierazten zuten. Epiktetok filosofo ziniko esploratzailearen irudia, kataskopos izenez ezagutua, deskribatu zuen: etsaiak zer egiten zuen ikustera gudarostearen aurretik joaten zen 
esploratzailea. Kataskoposaren antzera, zinikoa ere besteen aurretik joaten zen gizakiaren onerako eta txarrerako gauzak zein ziren esploratu eta erabakitzera. Zinikoak espioi- edo esploratzaile-lana egiten zuen; bidaia bakartia besteen aurretik egin ondoren, gizakien artera itzultzen zen gauza onen berri emateko (Foucault 2004). Parresia Biblian ere agertzen da, batez ere Joanen ebanjelioan, Apostoluen Ekintzetan eta Gutunetan. Filosofia zinikoaren eta hasierako kristautasunaren tradizioetan egia heterodoxo batekin elkartua ageri da parresia eta ohiko praktiken edo praktika onartuen kontra praktikatzen zen.

Parresiaren tradizioan, bere buruaz egia esan behar zuenaren (parresiastaren) alboan beste pertsona bat ere agertu zen: parresiastari egia esaten lagunduko zion laguntzailea, prestakuntza berezia behar zuena. Antzinako kulturan filosofoa izan zitekeen funtzio hori betetzen zuena. Kristautasunaren garaian aitorleek edo zuzendari espiritualek betetzen zuten aholkulariaren funtzioa. Kultura modernoan psikoanalistek, psikologoek, psikiatrek betetzen dute funtzio hori.

Parresiak bi esanahi zituen (Foucault 2009):

—Zentzu negatiboan, dena esatea, pasioak edo interesak eramanda mihira etorritako edozer gauza esatea adierazten zuen parresiak. Zentzu horretan, isilik egon ezin zen berritsua zen parresiasta.

- Zentzu positiboan hartuta, egia mozorrorik eta aho bizarrik gabe esatea zen parresia; egia esatea, ezer gorde gabe. Esandako egiak bat etorri behar zuen hitz egiten zuen pertsonaren iritziarekin. Parresiastak pentsatzen zuena esaten zuen eta esaten zuenari atxikitzen zitzaion; gainera, egia esateagatik arriskuren bat hartu behar zuen, eta arrisku horrek solaskide zuen pertsonarekiko harremana ukitzen zuen. Parresiastak esandako egiak haren eta entzulearen arteko lotura mehatxatzen zuen; beraz, parresiak adorea eskatzen zuen. Gerta zitekeen parresiastak esandakoa haren solaskideak onartzea eta bien arteko harremana ez haustea; kasu horretan parresiastak eta haren solaskideak adorea agertzen zuten.

Politikaren eremuan parresia praktikatzea eta askatasunaren alde adorez borrokatzea ezinbestekoa da, hiritarren gehiengoaren isiltasunari esker garatzen baitira sistema totalitarioak. Parresiari esker agintarien boterea mugatzen da. Beraz, filosofoak egia esan behar du boterearen aurrean (Foucault 2009).

Foucaultek parresia eta erretorika bereizi zituen. Parresiak adierazten zuen lotura indartsua zegoela parresiastaren eta hark zioenaren artean, baina arriskuan jartzen zuen hizlariaren eta entzulearen arteko lotura. Erretorikak gauzak esateko modua aztertzen zuen, ez zion begiratzen hizlariaren eta hark esandakoaren arteko harremanari. Erretorikari bost axola zitzaion hizlariak 
esaten zuena egia zen ala ez; erretoriko onak pentsatzen zuenaren kontrako zerbait esan zezakeen, eta hala ere entzuleak sinetsi egin behar zion. Erretorika ez zen zentratzen hitz egiten zuen pertsonaren eta hark esaten zuenaren arteko loturan; esaten zenaren eta entzuten zuenaren arteko loturari begiratzen zion (Foucault 2009).

\section{Adorearen osagaiak eta adore motak}

\subsection{Adorearen osagaiak}

Psikologiako ikertzaileen arabera, adoreak hainbat osagai ditu, baina ikertzaile guztiek ez dute dimentsio berberez hitz egiten:

— Peterson eta Seligmanen (2004) arabera, adorearen osagaiak ausardia, iraunkortasuna, entusiasmoa eta zintzotasuna dira. Ausardia: beldurraren aurrean ekiteko gaitasuna. Iraunkortasuna: eragozpenak eragozpen, helburura zuzendutako ekintzak egiten jarraitzeko borondatea. Entusiasmoa: bizitasuna, energia, kemena. Zintzotasuna: benetakotasuna, zuzentasuna, norbere buruarekin egiati izatea; bere barneko egoerak, konpromisoak eta asmoak islatzea.

- Fingeld (1995) eta Putmanen (1997) arabera, pertsona adoretsuak beldur-, mehatxu- edo zaurgarritasun-egoeran erakutsi behar du sendotasuna.

- Woodard eta Puryren (2007) arabera, beldur gehiago edo gutxiago sortzen duten mehatxuen aurrean, helburu garrantzitsu bat lortzeko borondatez eta desiraz jokatzen du adoretsua den pertsonak.

- Rate eta lankideen (Rate et al. 2007; Rate 2010) arabera, portaera batek, adoretsutzat hartua izateko, honako bost baldintza hauetatik lehen laurak bete behar ditu: 1) Borondatez eta nahita egindako ekintza da; 2) Beste pertsonen onurarako egindako ekintza da; 3) Jokaera adoretsua kontzienteki aukeratzen du, beste alternatiba batzuen artetik; 4) Portaera horrek ondoren negatiboak eduki ditzake ekintza egiten duenarentzat; 5) Portaera horrek egileari beldurra sor diezaioke, baina, hala ere, ekintza egitea erabakitzen du.

\subsection{Adore motak}

Honako adore mota hauek bereizten dituzte ikertzaileek:

- Adore fisikoa (Rate 2010): gudariak bere lurraldea babestean erakusten duena. Helburu edo balio batzuk lortu nahiak eramaten du heriotza edo kalte fisikoak ekar diezazkioketen portaera batzuetara. 
- Adore psikologikoa (Haase 1997): portaera-patroi kaltegarrien edo azalpenik gabeko barne-hersturaren aurrean tratamendu psikologiko gogorrak jasateko ausardia, heriotza psikikoari edo egonkortasun psikikoaren galerari aurre egiteko ausardia, eta aztura autosuntsitzaileen aurrean borroka egiteko borondatea.

- Adore soziala (Bierhoff 2002) duena benetako balioetan oinarritutako portaera bati lotzen zaio, eta beste pertsonen alde jokatzen du, jokaera horrek, sari zuzena ekarri ordez, kalte sozial handia ekar badiezaioke ere. Adore sozialak (Rate et al. 2007) jende boteretsuaren portaera okerrak salatzera eramaten du pertsona adoretsua eta salaketa horrek ondorio kaltegarriak izan ditzake salatzailearen ongizatean, irudi sozialean edo gizarteko harremanetan. Beste pertsonengatik interes hurbila sentitzera eta haiekin adiskidetasun luze batean konprometitzera eraman dezake adore sozialak. Beste pertsonekin harreman intimoa izateak ekartzen dituen arriskuak hartzeko zalantzarik ez du izaten. Harreman sakon batean murgil daiteke, non amaituko duen edo zernolako aldaketak eragingo dizkion jakin gabe. Adore sozialak bi beldur mota jartzen ditu elkarri aurrez-aurre (Rank 2004):

- Alde batetik, autonomia-gabeziak sortzen duen bizitzeko beldurra, baztertua izateko beldurra eta, ondorioz, beste norbaiten mendean egoteko beharra. Beldurra ematen dio bere burua baieztatu eta berresteak; ezin du beraren eta bestearen arteko distantziarik jasan; intimitateak beldurra ematen dio eta horrek harreman sinbiotikoetan murgiltzera bultzatzen du.

- Beste aldetik, autonomia eta nortasuna galtzeko beldurra dago: besteek erabat irentsiko ote duten beldur da. Zaila egiten zaio bere desiren, fantasien, asmoen eta beldurren berri besteei ematea.

- Adore moralaren osagaiak (Sekerka eta Bagozzi 2007; Lopez et al. 2003) eta adore sozialarenak antzekoak dira. Adore morala duen pertsona, talde sozial edo pertsona boteretsuren batekin ados ez dagoenean, haren kontra publikoki altxatzen da, bere ikuspegi, printzipio eta balioetan oinarrituta; adore moralez jokatzen duenak bortxatuak edo zapalduak diren pertsonen eskubideak defendatzen ditu. Egoera horietan salatzaileak (pertsona adoretsuak) salatuak baino botere gutxiago izan ohi du (Jonas eta Brandstaetter 2004); beraz, jokaera adoretsuak baztertze soziala, zigor ekonomikoa edo kalte fisikoa ekar diezazkioke. Greitemeyer eta lankideen arabera (Greitemeyer et al. 2006), pertsona adoretsuaren portaeraren helburua arau sozial eta etikoak indartzea da; ez die begiratzen portaeraren ondoren kaltegarriei.

Kostu sozialak bereizten ditu adore morala eta portaera prosoziala. Orain arte, ikerketa ugari egin dira portaera prosozialak aztertzeko (Batson 1998), baina gutxi egin dira egileentzat kostu sozial handia duten portaera proso- 
zialak ikertzeko. Adore morala eta ekintza prosoziala bereizten dituena portaeraren ondorio negatiboak igurikitzea da: portaera prosozialean ondorio positiboak espero izaten dira, baina adore morala gauzatzen den egoeretan ondorio sozial negatiboak (erasoak, baztertzeak, irainak) espero izaten dira.

Heroismoak eta adore moralak badituzte antzekotasun batzuk: heroiak ere arriskuak hartzen ditu besteen mesedetan, eta zauri fisikoak jasotzeko edo hiltzeko arriskuan jartzen du bere burua. Ondorio fisiko kaltegarriei dagokienez, adore morala eta heroismoa teilakatu egiten dira. Halere, ekintza heroiko bat egiten duenak ondorio sozial positiboak jasotzea espero izaten $\mathrm{du}$; aldiz, adore moralez jokatzen duenak ondorio negatiboak espero izaten ditu (Osswald et al. 2010; Becker eta Eagly 2004).

\subsection{Adorearen definizio berrirantz}

Goian aipatu ditugun adorearen definizio psikologikoetan honako osagai hauek agertzen dira: 1) Pertsona adoretsuak asmo bat edo helburu bat lortu behar du besteen onerako. 2) Helburua lortzera zuzendutako ekintzak egiten jarraitzeko sendotasuna eta iraunkortasuna behar ditu, horrek arriskuak jasatera eta zaurgarri izatera eramango badu ere. 3) Egoera horretan gizarteko kide indartsuei aurre egin behar die, bakartua gelditzeko arriskuarekin, min fisikoa edo psikikoa ekar dezaketen ekintzak eginez. 4) Adore-ekintza egiteko erabaki kontziente eta boluntario bat hartu behar du. 5) Benetakotasuna: pentsatzen eta sentitzen duenarekin bat dator egiten duena. 6) Arriskuak arrisku, beldurrak beldur eta mehatxuak mehatxu, pertsona adoretsua inguruan ekiteko gai sentitzen da.

Halere, filosofiaren historian erreparatu ditugun gogoeten arabera, badira adorearen beste alderdi batzuk ere, adorearen ikerketa psikologikoa egiterakoan kontuan hartzeko modukoak:

- Agertoki publikoko adorea eta ezkutuko adorea bereizi behar dira, adore-ekintzak jendaurrean edo bakardadean egin baitaitezke.

- Adorearekin batera beste bertute positiboak badituen ala ez aztertu behar da.

- Klase-maila ezberdineko jendearen adorea eta arlo ezberdinetako adoreak bereizi behar dira.

- Adoreak ongia egiteko edo gaizkiari ihes egiteko indarra adierazten du. Idealaren alde eta gaizkiaren kontra borrokatzen diren adoreak bereizi behar dira.

- Nagikeriaren eta borondatearen biguntasunaren kontrako balioa da adorea.

- Gogoeta teorikoarekin, ekoizpen ordenatuarekin eta adostasunarekin erlazionatutako adorea eta borrokarekin, gatazkarekin eta entsegu esperimentalekin erlazionatutako adorea aztertu behar dira. 
- Bere kabuz pentsatzeko eta babes-egoeratik irteteko gaitasuna du pertsona adoretsuak.

- Maila indibidualeko adorea eta maila kolektibokoa alderatu behar dira.

- Behe-mailakoekin elkartasun-loturak josten laguntzen duen adorea eta gizartearen erpinera igotzen laguntzen duen adorea alderatu behar dira.

- Barne-hersturari aurre egiteko adorea eta objektu beldurgarri bati aurre egiteko adorea bereizi behar dira.

- Ekintza-askatasunerako bidea irekitzen duen adorea eta bizitzarekiko atxikimenduarekin erlazionatzen den adorea alderatu behar dira.

- Mozorroa kendu eta bere burua benetan den bezala agertzen duen pertsonaren adorea aztertu behar da; intimitatea agertzeko beldurrari aurre egiten dion adorea ikertu behar da.

- Egoera zailetan egia esateko eta onartzeko adorea norberaren klasemailarekin edo bizitzaren erosotasunarekin erlazionatu behar da.

- Adorez jokatzen duen pertsonak ekintza adoretsutik kaltea ala onura ateratzen duen ikusi eta adoreak alderatu behar dira.

\section{Ondorioak}

Homeroren heroiek jendaurrean, besteen begien aurrean, agertzen zuten adorea. Heroi horiek ez zituen mugitzen barne-motibazioak edo motibazio psikologikoak; ez zuten berek erabakitzen zer egin behar zuen, patuak gidatzen zituen.

Sokratesek eta Platonek adorearen nozioa moralizatu, intelektualizatu eta pertsonaren barne-motibazioekin erlazionatu zuten. Adorea ez zen gudu-zelaian bakarrik adierazten, beste arlo batzuetan ere adierazten zen: gaixotasunaren aurrean, itsasoko arriskuen aurrean, desiren aurrean. Adorea pertsona guztiek eduki zezaketela pentsatzen zuten.

Aristotelesentzat, heriotza noble baten larritasunei beldurrik gabe aurre egiten ziena zen pertsona adoretsua. Gudu-zelaira mugatu zuen berriro ere adorea. Platonentzat edonor izan zitekeen adoretsua, baina Aristotelesek nobletasuna itzuli zion adoreari.

Agustinek eta beste pentsalari kristauek politikaren eremutik alde egin eta adorearen psikologian sakontzen jarraitu zuten. Lanari lotuta, azediaren, nagikeriaren eta borondatearen biguntasunaren kontrako baliotzat hartzen zuen adorea. Pertsona adoretsua izatea gaizkiaren kontra borrokatzean zetzan, idealaren bila joatean baino gehiago. Kristauen morala apaltasunaren etika zen, besteen begiradari ihes egiten zion. Agustinen jarraitzaileek pentsatzen zuten anabasak ez zuela politikarekin zerikusirik; ordenarik eta botererik ezin sor zitekeela gatazka eta desordena besterik ez zegoen lekuan. 
Tomas Akinokoarentzat, zauritua izateko eta martiri bihurtzeko arriskua onartu behar zuen pertsona adoretsuak. Adore-gabezia eta bizitzarekiko atxikimendu handiegia gaixotasuntzat zeuzkan. Adore-ekintza bakardadean gauzatzen zen; bizitzako gertaerarik bakartiena eta adore gehien eskatzen zuena heriotza zen. Pertsona adoretsuak arriskuei aurre egin eta tinko irauteko beldurra menderatu behar zuen; adorearen osagai nagusia arriskuen aurrean mugitu gabe egotea eta tinko eustea zen.

Aro Modernoan desagertu egin zen adoreari eta moral transzendenteari buruzko diskurtsoa, eta zalantzan jarri ziren antzinateko moralaren oinarrizko printzipioak. Beldurra eta interesa bihurtu ziren aro modernoko pasio nagusi. Gizarte zibilizatua interesaren eta merkatalgoaren gain egituratuko zen. Interesak partekatzeak grinak erregulatzeko aukera ematen zuen.

Makiavelori tamalgarria iruditzen zitzaion Aristotelesen erdibidearen teoria eta gogor kritikatzen zuen teoria hori; neutraltasuna ez zitzaion gustatzen. Makiavelok arrazoiaren lehentasuna baztertu egin zuen; izan ere, haren iritziz, erromatarrek ez zuten beren lurraldea arrazoimenaren arabera antolatu, borroka eta entsegu ugariren bidez baizik.

Spinozarentzat, adorea adierazi nahi zuenak ez zuen bere burua sakrifikatu behar; pertsona adoretsuak bere burua eta besteak maitatu behar zituen. Gizaki aske eta adoretsua bizitzaz eta energiaz beterik zegoen eta arrazoiaren aholkuak jarraitzen zituen; haren portaera ez zuen beldurrak gidatzen. Spinozarentzat, pertsona adoretsuak ez zuen bere bizitza mespretxatzen.

Erdi Aroko gizakiak mirabetza onartu zuen eta babes-egoeran bizitzen jarraitu nahi izan zuen; ez zuen adorerik izan adimena erabiliz egoera aldatzeko. Babes-egoeran jarraitu zuen, ez adimen gutxiegi zuelako, baizik eta erabakimen eta adore gutxi zuelako. Ilustrazio aroko gizakia bere babes-egoeratik irten eta bere adimena erabiltzen hasi zen. Bere kabuz pentsatzen hasteko eskatu zion Kantek gizakiari. Beldurrak eta nagikeriak paralizatutako adimenari aurre eginez, arrazoia erabiltzearen aldeko apustua egin zuen Kantek.

Pentsamendu garaikidean, adore indibidualaren kontzepzio klasikoaren aurrez aurre, adorearen dimentsio kolektibo eta anonimoa azpimarratu zen.

Nietzschek Homeroren heroien balio moralak aldarrikatu zituen: indarra, adorea, begirunea, handitasuna, noblezia eta ohorea. Nietzscheren heroia pertsona kaxkarren gainetik nabarmentzen eta boterearen erpinera igotzen saiatzen zen. Heroiak balio-sistema bat sortu behar zuen, herriaren gidari bihurtu behar zuen eta bere legea eta morala ezarri behar zizkien masei.

Paul Tillichentzat, ez-izatearen eta mugen kontzientziak barne-herstura ontologikoa sortzen zion gizakiari; mundua ez zela beti eta ezinbestean orduan zen bezalakoa izango jakiteak antsietatea sortzen zion. Barne-herstura 
ezin zuen uxatu, haren jatorria ezerezean zegoelako eta objekturik ez zuelako. Adoretsua ez zen pertsonak barne-hersturari objektu bat seinalatzen zion eta beldur bihurtzen zuen, beldurrari adorez aurre egin ahal izateko.

Arendten iritziz, bertute nagusia adorea zen eremu politikoan eta pertsona adoretsua askatasunak gehiago kezkatzen zuen bizitza soilak baino; askatasunaren esperientzia-eremuan gertatzen ziren ekintza gatazkatsuek eta borrokak ematen zioten zentzua bizitzari. Adoreak bizitzako premietatik eta atxikimenduetatik askatzen eta ekintzen askatasunera irekitzen zituen gizakiak. Pertsona adoretsuak bere kontrola eta maisutasuna galtzea onartzen zuen. Nortasun etikoa eraiki nahi zuenak bere burua aztertzeko eta egia esateko eta onartzeko adorea eduki behar zuen.

Foucaulten iritziz, nortasun etikoa eraikitzeko egia esateko adorea behar zen; egia ekoizteko parresia praktikatu behar zen. Parresiastak egia esaten zuen, mozorrorik eta apaingarri erretorikorik gabe, horrek arazoak sortzen bazizkion ere.

Amaitzeko, pertsona adoretsuaren bereizgarriak deskribatuko ditugu:

— Beste pertsonen eskubideak defendatzea eta babestea erabakitzen du modu kontzientean.

- Adore-ekintzak batzuetan jendaurrean eta besteetan isilean edo pribatuan egiten ditu.

- Pertsonak egiten duena bat dator berak benetan pentsatzen eta sentitzen duenarekin.

- Gizaki adoretsuak prest daude mozorroa kendu eta benetan diren gisara agertzeko edo beren intimitatea agertzeko.

- Gizaki adoretsu batzuek, adoreaz gain, beste bertute batzuk ere izaten dituzte; adibidez, adimentsuak edo borondatetsuak izan daitezke.

- Adorea gogoeta teorikoarekin, ekoizpen ordenatuarekin eta adostasunarekin edo borrokarekin, gatazkarekin eta entsegu esperimentalekin erlaziona daiteke.

- Pertsona adoretsuak ongia egiteko edo gaizkiari ihes egiteko balia dezake adorea.

— Arriskuen eta egoera zailen aurrean tinko mantentzen da pertsona adoretsua.

- Arriskuak arrisku, beldurrak beldur eta mehatxuak mehatxu, pertsona adoretsua inguruan ekiteko gai sentitzen da.

- Pertsona adoretsuak babes-egoeratik irten eta bere kabuz pentsatzeko gai dira.

- Bizitzako premia eta atxikimenduetatik askatu eta ekintza-askatasunerako bidea irekitzen du pertsona adoretsuak.

- Pertsona adoretsuak, batzuetan, elkartasun-loturak josten ditu behemailakoekin eta, bestetan, ekintza adoretsuen bidez gizartearen erpinera igotzeko ahaleginak egiten ditu. 
- Adorea maila indibidualean edo maila kolektiboan gauza daiteke.

- Gizaki adoretsuak ez-izatearen barne-hersturari aurre egiten dio.

- Pertsona adoretsua egoera zailetan egia esateko eta egia onartzeko gai da.

- Pertsona adoretsuak sarritan gizarteko kide boteretsuen esker txarra, kritika eta zigorra jasotzen ditu.

\section{Erreferentzia bibliografikoak}

ARENDT, Hannah (1972), La crise de la culture. Paris: Gallimard.

ARENDT, Hannah (1983), La condition de l'homme moderne. Paris: Calmann-Lévy. Pocket Agora bilduma.

Aristoteles (K.a. 350), Nicomachean Ethics. http://classics.mit.edu/Aristotle/ nicomachaen.1.i.html

BADIOU, Alain (2007), Logics of Worlds. Being and Event. London eta New York: Bloomsbury.

BASsI, Karen (2003), «The semantics of manliness in ancient Greece». In Ralpf. M. Rosen eta Ineke Sluiter (arg.), Andreia: Studies in Manliness and Courage in Classical Antiquity. Leiden: Bril, 25-58 or.

BATSON, C. Daniel (1998), «Altruism and prosocial behavior». In Daniel T. Gilbert, Susan T. Fiske eta Gardner Lindzey, The handbook of social psychology. New York: McGraw-Hill, 282-316 or.

BECKER, Selwyn eta EAgly, Alice (2004), «The heroism of women and men». American Psychologist 59: 163-178.

Berns, Thomas, BlÉsin, Laurence eta Jeanmart, Gaëlle (2010), Du courage. Une histoire philosofique. Paris: Les Belles Lettres.

Bierhoff, Hans-Werner (2002), Prosocial behavior. New York: Psychology Press.

FINGELD, Deborah L. (1995), «Becoming and being courageous in the chronically ill elderly». Issues in Mental Health Nursing 16: 1-11.

Florian, Victor, Mikulincer, Mario eta TAubman, Orit (1995), «Does hardiness contribute to mental health during a stressful real-life situation?. The roles of appraisal and coping». Journal of Pertsonality and Social Psychology 68 (4): 687-695.

Foucault, Michel (2009), Le courage de la vérité. Le gouvernement de soi et des autres. Cours au Collège de France 1983-1984. Paris: Gallimard-Le Seuil («Hautes Etudes» bilduma).

Foucault, Michel (2004), La hermenéutica del sujeto. Mexiko: Fondo de Cultura Económica.

FReUd, Sigmund (1900), The Interpretation of Dreams. Londres: Hogarth and the Institute of Psychoanalysis.

GaVRaY, Marc-Antoine (2009), «Le courage, du relativisme de Protagoras à l'unité platonicienne des vertus». In G. Jeanmart eta L. Blésin (arg), Figures du courage politique dans la philosophie moderne et contemporaine. Dissensus Revue de philosophie politique de l’ulg (2), 2.

Greitemeyer, Tobias, Fischer, Peter, Kastenmüller, Andreas eta Frey, Dieter (2006), «Civil courage and helping behaviour: Differences and similarities». European Psychologist 11: 90-98. 
HAASE, Joan (1997), «Hopeful teenagers with cancer: Living courage». Reflections / Sigma Theta Tau 23 (1): 20.

Heidegger, Martin (2008), Being and time. New York: Harper Perennial Modern Thought.

Herzog, Annabel (2004), «Hannah Arendt's Concept of Responsibility». Studies in Social and Political Thought 10: 39-52.

JEANMART, Gaëlle eta BlÉsin, Laurence (2009), «Figures du courage politique dans la philosophie moderne et contemporaine». Dissensus Revue de philosophie politique de l'ULg (2), 2.

Jonas, Kai eta Brandstaetter, Veronika (2004), «Zivilcourage. Definition, Befunde, Maßnahmen»[«Moral courage. Definition, findings, and interventions»]. Zeitschrift für Sozialpsychologie 35: 185-200.

KANT, Emmanuel (1790/2000), Critique de la facuté de juger. Paris: Flammarion.

KANT, Emmanuel (1784/1991), Qu'est-ce que les Lumières?. Paris: Flammarion, GF bilduma.

Kernis, Michael H. eta Goldman, Brian M. (2006), «A multicomponent conceptualization of authenticity: Theory and research». Advances in Experimental Psychology 38: 283-356.

KRAUT, Richard (2004), «Plato». In Edward N. Zalta (arg.), The Stanford Encyclopedia of Philosophy. http://plato.stanford.edu/archives/sum2004/entries/plato/

LA Bó́TIE, Etienne de (1576/1993), Discours de la servitude volontaire. Paris: Imprimerie Nationale. https://www.institutcoppet.org/wp-content/uploads/2011/07/Discoursde-la-servitude-volontaire.pdf

LACAN, Jacques (2004), Le Séminaire, livre X, L'angoisse (1962-63). Paris: Le Seuil.

LARSEN KNUD, S. eta GILLES, Howard (1976), «Survival or courage as human motivation: Development of an attitude scale». Psychological Reports 39 (1): 299-302

Lopez, Shane J., O’Byrne, Kristin K., eta Peterson, Stephanie (2003), «Profiling Courage». In S. J. Lopez eta C. R. Snyder (arg.), Positive Psychological Assessment: A Handbook of Models and Measures, Washington DC: American Psychological Association, 185-197.

Machiavello, Nicolai (1622), Princeps. Francofurti: sumptibus Haeredum Lazari Zetneri.

MARTY, Olivier (2011), Ethiques heroïques et tautomachie. Les valeurs du combat selon Frédéric Nietzsche. Thèse de philosophie. Paris Ouest: Nanterre La Défense.

MasLow, Abraham H. (1970), Motivation and pertsonality. New York: Harper eta Row.

MAY, Rollo (1969), Love and will. New York: Norton \& Company.

MaY, Rollo (1975), The Courage to Create. New York: Norton \& Company.

Miller, Rielle (2005), Moral Courage: Definition and Development. Ethic Resource Center. http://www.emotionalcompetency.com/papers/Moral_Courage_Definition_and_Development.pdf

Nietzsche, Friedrich (1898), Par dela le bien et le mal. Paris: Société du Mercure de France.

Nietzsche, Friedrich (1900), La généalogie de la Morale. Paris: Société du Mercure de France.

Osswald, Silvia, Greitemeyer, Tobias, Fischer, Peter eta Frey, Dieter (2010), «What Is Moral Courage? Definition, Explication, and Classification of a Complex Construct». In C. L. Pury eta S. J. Lopez (arg.), The Psychology of Courage: Modern Research on an ancient virtue, Washington, DC: American Psychological Association, 149-164 or. 
PEARS, David (2004), «The Anatomy of Courage». Social Research 71 (1): 1-13.

Peterson, Christopher eta Seligman, Martin (2004), Character strengths and virtues: A classification and handbook. New York: Oxford University Press.

Platon (K.a. 399-385/K.o. 1952), IV Laches, Protagoras, Meno, Euthydemus. Cambridge, Massachusetts: Harvard University Press.

Platon (K.a. 389-385/K.o. 1959), Gorgias. Oxford: Clarendon Press.

Putman, Daniel (1997), «Psychological Courage». Philosophy, Psychiatry, and Psychology $4(1): 1-11$.

Rank, Otto (2004), The Myth of the Birth of the Hero. Baltimore: John Hopkins University Press.

Rate, Christopher, Clarke, Jennifer, Lindsay, Douglas eta Sternberg, Robert (2007), «Implicit theories of courage». The Journal of Positive Psychology 2: 80-98.

RATE, Christopher (2010), «Defining the features of courage: A search for meaning». In C. Pury eta S. Lopez (arg.), The psychology of courage: Modern research on an ancient virtue, Washington, DC: American Psychological Association, 47-66 or.

ROGERS, Karl R. (1961), On becoming a person: A therapist's view of Psychotherapy. Boston: Houghton Mifflin.

Rosen, Ralph M. eta SLuiter Ineke (2003), Andreia: studies in manliness and courage in classical antiquity. Leiden, Boston: Brill.

RudA, Frank (2017), «Philosophy and Courage». Problemi International 1 (1): 33-54.

RyfF, Carol D. eta KeYes, Corey Lee M. (1995), «The Structure of Psychological WellBeing Revisited». Journal of Pertsonality and Social Psychology 69 (4): 719-727.

SEKERKA, Leslie E. eta BAgOzzI, Richard P. (2007), «Moral Courage in the Workplace: Moving to and from the Desire and Decision to Act». Business Ethics: A European Review 16 (2): 132-149.

Sheldon, Kennon M., Ryan, Richard M., Rawsthorne, Laird J. eta Ilardi, Barbara (1997), «Trait self and true self: Cross-role variation in the Big-Five pertsonality traits and its relations with psychological authenticity and subjective well-being». Journal of Pertsonality and Social Psychology 73: 1380-1393.

Tillich, Paul (1952), The Courage To Be. New Haven: Yale University Press.

TомаS АкіnокоA (1265-1274), Summa Theologiae http://www.ccel.org/ccel/aquinas/ summa.pdf

Wilburn, Josh (2015), «Courage and the Spirited Part of the Soul in Plato's Republic». Philosopher's Imprint 15 (26): 1-21.

WoOdard, Cooper eta Pury, Cynthia L. S. (2007), «The construct of courage: Categorization and measurement». Consulting Psychology Journal: Practice and Research 59 (2):135-147.

Zavaliy, Andrei G. eta Aristidou, Michael (2014), «Courage: A Modern Look at an Ancient Virtue». Journal of Military Ethics 13 (2):174-189. 